\title{
A note on India's water budget and evapotranspiration
}

\author{
T N NARASIMHAN \\ Department of Materials Science and Engineering, 210 Hearst Memorial Mining Building, \\ University of California, Berkeley, Ca 94720-1760, USA. \\ e-mail: tnnarasimhan@lbl.gov
}

Some recent analyses of India's water budget are based on information attributed to the Ministry of Water Resources. An examination of the budget components indicates that they imply an evapotranspiration estimate that is significantly lower than what one may expect based on information from other sources. If such is the case, India's water resources situation may be more dire than is otherwise perceived. For, higher evapotranspiration implies correspondingly reduced availability of water for human use. It should be worthwhile to investigate and reconcile the apparent discrepancy between water budget and evapotranspiration, considering the importance of water in the national context.

\section{Introduction}

India's water budget has been discussed by Gupta and Deshpande (2004), Kumar et al (2005), and Garg and Hassan (2007). Additionally, it has also played a role in an expert group report on groundwater management and ownership (Planning Commission 2007). These analyses are based on estimates of water budget components presented in a report by the National Commission for Integrated Water Resources Development Plan (Ministry of Water Resources 1999).

Although water budget is essential for comprehending the status of water availability and use, grasping the significance of the magnitudes of the budget components requires much effort. One way to verify the internal consistency of India's water budget components is to examine the magnitude of evapotranspiration implicit in them, and see if the estimate so arrived is compatible with evapotranspiration estimates from other sources. Such a comparison as presented below, shows that an apparent discrepancy in fact exists between India's water budget and evapotranspiration. The purpose of this technical note is to bring this discrepancy to the attention of the general earth-science community, and to suggest that the discrepancy merits reconciliation through further studies, considering the importance of water budget in the nation's natural resources context. It is hoped that researchers in surface water hydrology, meteorology, and climatology who have the necessary expertise will investigate and help to reconcile the discrepancy.

\section{Water budget and evapotranspiration}

Water budget, in its elementary form, can be represented by the equation:

$$
\begin{aligned}
\text { Total rainfall input }= & \text { Surface water flows } \\
& + \text { Groundwater recharge } \\
& + \text { Evapotranspiration }
\end{aligned}
$$

This equation neglects stream inflows into India from outside its borders. The water budget figures used by the aforesaid authors, based on estimates provided by the Ministry of Water Resources (1999), involve three of the quantities in (1), except evapotranspiration. The magnitudes of the three components are as follows:

Keywords. India; water budget; evapotranspiration; water policy; water management. 
Table 1. Principal annual components of India's water budget ${ }^{1}$.

\begin{tabular}{lll}
\hline Component & \multicolumn{1}{c}{ Volume $\left(\mathrm{km}^{3}\right)$} & \multicolumn{1}{c}{ Precipitation (\%) } \\
\hline Precipitation & 3838 & 100 \\
Potential flow in rivers & 1869 & 48.7 \\
Natural recharge & 432 & 11.3 \\
Available water & $1869+432=2301$ & 60 \\
Evapotranspiration & $3838-(1869+432)=1537$ & $100-(48.7+11.3)=40.0$ \\
\hline
\end{tabular}

${ }^{1}$ Gupta and Deshpande (2004); Planning Commission (2007).

Table 2. Average annual evapotranspiration as percentage of average annual precipitation for some regions of the world.

\begin{tabular}{|c|c|c|c|c|}
\hline \multirow[b]{2}{*}{ Region } & \multirow[b]{2}{*}{ Area $\left(10^{6} \mathrm{~km}^{2}\right)$} & \multicolumn{2}{|c|}{ Evapotranspiration } & \multirow[b]{2}{*}{ Reference } \\
\hline & & ET only (\%) & $\mathrm{ET}+$ Infiltration $(\%)$ & \\
\hline World's land & 148.9 & - & $\begin{array}{l}60.5-66.4 \\
(3 \text { estimates })\end{array}$ & Shiklomanov (1997) \\
\hline Australia & 7.66 & 90 & - & $\begin{array}{l}\text { Australian Water Resources } \\
(2005)\end{array}$ \\
\hline Amazon basin & 6.2 & $\begin{array}{l}59.4-82.1 \\
\text { (4 estimates) }\end{array}$ & - & Marengo (2006) \\
\hline $\begin{array}{l}\text { La Plata basin } \\
\text { South America }\end{array}$ & 3.2 & - & $\begin{array}{l}73.2(1951-1970) \\
67.7(1980-1999)\end{array}$ & Berbery and Barros (2002) \\
\hline France & 0.55 & 62.0 & 82.8 & $\begin{array}{l}\text { Institut Français de } \\
\text { L'Environment (2004) }\end{array}$ \\
\hline California & 0.41 & 69.8 & - & $\begin{array}{l}\text { Department of Water Resources } \\
(2005)\end{array}$ \\
\hline United States & 9.16 & 70 & - & Leopold (1974) \\
\hline India & 3.28 & 69.5 & 74.5 & Jain et al (2007) \\
\hline India & 3.28 & 40 & 51.3 & $\begin{array}{l}\text { Gupta and Deshpande (2004) } \\
\text { Planning Commission (2007) }\end{array}$ \\
\hline
\end{tabular}

\subsection{Total rainfall input}

India's average annual rainfall, as seen in Planning Commission (2007), is $1170 \mathrm{~mm}$. India's land area is 3.28 million sq. kms., as seen from the country's profile (National Portal of India 2008). The product of these two quantities yields, for India's total rainfall input, $3838 \mathrm{cu} \mathrm{kms.} \mathrm{Both} \mathrm{Gupta}$ and Deshpande (2004) and Planning Commission (2007) present, for total rainfall input, $4000 \mathrm{cu} \mathrm{kms.}$ It seems reasonable to assume that the figure 3838 has been rounded off to 4000 .

\subsection{Surface water flows and groundwater recharge}

Of the total rainfall, $1869 \mathrm{cu} \mathrm{kms}$ constitutes average annual potential flow in rivers, while $432 \mathrm{cu} \mathrm{kms}$ is considered to be replenishable groundwater.

These figures are presented in table 1, along with the magnitude of evapotranspiration implicit in them on the basis of (1). The figures in table 1 imply that evapotranspiration is $40 \%$ of total rainfall. The remaining $60 \%$ constitutes water accessible for human use. If estimates of India's evapotranspiration from other sources significantly differ from this estimate of $40 \%$, then such a discrepancy should merit careful evaluation and reconciliation.

\section{Comparison with other sources}

It is common practice to estimate evapotranspiration in two different ways. On the basis of (1), the first is to subtract surface runoff plus groundwater replenishment from total precipitation. The second is to estimate evapotranspiration using mesoscale climate models that use energy balance techniques. By definition, evapotranspiration is that part of rainfall that does not contribute to flow (surface or underground). 
Table 3. Temporal variability of annual average evapotranspiration for two regions.

\begin{tabular}{lllllll}
\hline \multirow{2}{*}{ Region } & \multicolumn{2}{c}{ Wet year } & \multicolumn{2}{c}{ Normal year } & \multicolumn{2}{c}{ Dry year } \\
\cline { 2 - 7 } & Period & ET, $(\%)$ & Period & ET, (\%) & Period & ET, $(\%)$ \\
\hline Amazon basin $^{1}$ & $1988-1989$ & $65.7 \%$ & $1982-1983$ & $74.1 \%$ & $1997-1998$ & $79.0 \%$ \\
California $^{2}$ & 1998 & $63.4 \%$ & 2000 & $69.8 \%$ & 2001 & $90 \%$ \\
\hline${ }^{1}$ Marengo (2006). & & & & \\
${ }^{2}$ Department of Water Resources (2005).
\end{tabular}

In order to assess the credibility of the evapotranspiration estimate in table 1 , we now proceed to compare it with published values of evapotranspiration for six regions of the world with varying areal extent, climatic regimes, and landscape characteristics. In addition, an evapotranspiration estimate for India is presented from a source other than the Ministry of Water Resources. Estimates are also included for the world's land area as a whole. The pertinent data are summarized in table 2, along with their sources.

It is seen from the third column of table 2 that the estimates for evapotranspiration alone, exclusive of subsurface recharge, vary between 59.4 and 90 per cent, significantly larger than the $40 \%$ implied in Gupta and Deshpande (2004), and Planning Commission (2007). It is also worth noting that Jain et al (2007) give an estimate of $69.5 \%$ for India's evapotranspiration. Clearly, estimates of evapotranspiration are subject to methodological limitations and uncertainties. Even accounting for these uncertainties, it is apparent that the estimate $40 \%$ inherent in Ministry of Water Resources (1999) appears to be a significant underestimation of India's evapotranspiration.

\section{Temporal and spatial variability}

Evapotranspiration, just as precipitation, is subject to variability in space and time. For a credible comprehension of long-term water resource availability, it is necessary to have an understanding of these variabilities in addition to the average annual estimates.

Evapotranspiration will vary noticeably from year to year, depending on whether precipitation for a given year is above or below normal. Marengo (2006) and Department of Water Resources (2005) provide estimates for temporal variation of evapotranspiration for the Amazon Basin and for the state of California respectively. Their findings, presented in table 3 show that between wet and dry years evapotranspiration varies from $65.7 \%$ to $79 \%$ for the Amazon Basin, and 63.4 to $90 \%$ for California. If these estimates are any indication, India's evapotranspiration may in fact exceed the $69.5 \%$ indicated by Jain et al (2007) during years of below-normal rainfall.

\section{Discussion}

In the last section it has been shown that an estimate of $40 \%$ for India's evapotranspiration implicit in Gupta and Deshpande (2004) and Planning Commission (2007) is significantly smaller than published estimates for a number of regions in the world, varying widely in land area, climatic setting and landscape. In particular, Jain et al (2007) estimate India's evapotranspiration to be $69.5 \%$, almost $30 \%$ larger than the other estimate. In as much as evapotranspiration represents consumptive use (that is, water not available for human use), larger evapotranspiration implies correspondingly reduced availability of water amenable for human use. As seen from table 1 , the $40 \%$ evapotranspiration estimate corresponds to $2301 \mathrm{cu} \mathrm{kms} \mathrm{of} \mathrm{available} \mathrm{water.} \mathrm{However,}$ consistent with their evapotranspiration estimate, Jain et al (2007) estimate available water to be $1460 \mathrm{cu} \mathrm{kms}(1260 \mathrm{cu} \mathrm{kms}$ of surface flow plus $200 \mathrm{cu} \mathrm{kms}$ of groundwater recharge). The difference, $842 \mathrm{cu} \mathrm{kms}$, constitutes an almost $37 \%$ reduction in the expected water availability.

The foregoing discrepancy has major implications to India's water resources planning. India's 'estimated utilizable water resources' is $1122 \mathrm{cu}$ kms (Gupta and Deshpande 2004; Planning Commission 2007). This constitutes $48.8 \%$ of the available water resources of $2301 \mathrm{cu} \mathrm{kms}$ (table 1) implying that, for technological and environmental reasons, a little less than half will be actually amenable to extraction for human use. Finally, current water use in India is estimated to be $634 \mathrm{cu} \mathrm{kms,} \mathrm{which} \mathrm{is} 56.5 \%$ of 'estimated utilizable water resources'. Based on this, one could infer that India's water demand will outstrip supply a few decades from now.

Instead, if we were to use the estimate of $1460 \mathrm{cu} \mathrm{kms}$ for available water, and assume 48.8\% extractability, then 'estimated utilizable water resources' reduces to $712 \mathrm{cu} \mathrm{kms}$ from $1122 \mathrm{cu} \mathrm{kms}$. 
If we compare this $712 \mathrm{cu} \mathrm{kms}$ with the current use of $634 \mathrm{cu} \mathrm{kms}$, it is clear that India is already at the threshold of over development of water resources. Thus, India has to be seriously concerned about shortage of water right now, rather than a few decades from now.

If the arguments presented above are reasonable, what needs to be done now? The suggestion is that the earth-science community comprising hydrologists, soil scientists, meteorologists, and climatologists would do well to devote attention to generate a water budget in which the components, including evapotranspiration, are mutually consistent. To this end, it will be necessary to critically evaluate available stream flow data and infiltration data. Complementing this, independent estimates of evapotranspiration need to be made based on mesoscale climate models. Garg and Hassan (2007) report that water resources data are treated as classified material by the government. If so, the effort could be impeded by difficulty of data access.

\section{Concluding remark}

India's water budget, as provided by the Ministry of Water Resources (1999), is widely used as the basis for making projections about India's water future, and related policy matters. There is sufficient evidence to suggest that the budget estimates may be seriously overestimating available water resources and utilizable water resources. It is hoped that this technical note would motivate researchers in surface water hydrology, meteorology, and climatology to revisit India's water budget and provide credible revised estimates, which would be of broad interest to earth scientists, water managers, policy makers and the concerned citizens.

\section{References}

Australian Water Resources 2005;

http://www.water.gov.au/WaterAvailability/

Berbery E H and Barros V R 2002 The hydrological cycle of the La Plata Basin in South America; J. Hydromet. 3 630-645.

Department of Water Resources, State of California 2005 Water Plan Update 2005, Public Review Draft, Vol. 3

Garg N K and Hassan Q 2007 Alarming scarcity of water in India; Curr. Sci. 93 932-941.

Gupta S K and Deshpande R D 2004 Water for India in 2050: first order assessment of available options; Curr. Sci. 86 1216-1224.

Institut Français de L'Environment 2004 L'état des eaux souterraines en France, aspects quantitatifs et qualitatifs. Report, Institut français de l'environnement, Orléans, Etudes et Travaux n ${ }^{\circ} 43,34$ pp.

Jain S K, Agarwal P K and Singh V P 2007 Hydrology and Water Resources of India (The Netherlands: Springer, Dordrecht) $1258 \mathrm{p}$.

Kumar R, Singh R D and Sharma K D 2005 Water resources of India; Curr. Sci. 89 794-811.

Leopold L B 1974 Water: a primer (San Francisco: W. H. Freeman) 172 p.

Marengo J A 2006 On the hydrological cycle of the Amazon Basin: A historical review and current state-of-the-art; Revista Brasileira de Meteorologia 21 1-19.

Ministry of Water Resources, Government of India 1999 Integrated water resources development - a plan for action; Report of the National Commission for integrated water resources development plan, Vol 1, p. 515

National Portal of India 2008 http://india.gov.in/knowindia/profile.php

Planning Commission 2007 Report of the Expert Group on Ground Water Management and Ownership, Government of India, New Delhi, September 2007.

Shiklomanov I A 1997 Comprehensive assessment of the freshwater resources of the world; World Meteorological Organization, 88 pp. 